\section{Sarcoidosis 의 疫學}

(연령별, 인종별, 직업별, 지역별, 임상적 특성)

\section{Hospital, Age, Racial, Occupational, Geographic, Clinical and Survivorship Characteristics in the Epidemiology of Sarcoidosis}

Andrew Z. Keller

American Journal of Epidemiology Vol.94, No. 3, Sept., 1971

Sarcoidosis 의 원인에 대해서는 잘 알려져 있지 않았 지 만 인종별, 년령별, 지역별분포에 대해서 일반적으로 알려진바 있다.

Sarcoidosis 의 疫學的인 요소에 있어서 특히 지리적 인 분포가 차이를 이루고 있다고 하는 것은 여러학자들 이 연구한 결과 공론적인 것이다.

본연구는 미국 Veteran's Hospital 에서 1960년에서 1964년 까지 Sarcoidosis case 420명에 대하여 그들의 인 종별, 연령별, 직업별, 지리적분포 등으로 구분하여 연 구를 실시한 것이다.

임 상적으로 bronchitis, emphysema, pulmonary tuberculosis 와의 연관성도 아울러 관찰을 하였다.

\section{재료 및 방법}

조사대상은 1960년에서 1964년까지 미국내에 있는 모 든 Veteran's hospital 에서 가료중인 sarcoidosis cases 420 명을 대상으로 했으며 모두 남자로 택했다. 420명중 에 Negro가 234, White가 186 명이였다. 420 명에 대 한 대조군을 설정했다. 대조군을 인종별, 년령군별, 병 원크기별로 구분하여 선정한 것이다.
결핵 및 호홉기질환 Vol. 19, No. 1, Jan., 1972

처음 진 단된 315 명 case 와 그대조군에 대해서는 bronchitis, emphysema, pulmonary tuberculosis 와의 연관성을 관찰하였다. 모든 환자에 대한 조사는 임상적 인 기록 및 sarcoidosis 진단에 관계되는 병리학적인 데 이타를 기준하여 실시되었다.

결 과

\section{1. 병원크기별 환자분포}

병원의 크기는 침상수에 따라서 구분을 하였는데 즉 100 499beds, 500 899beds, 900 1, 499beds, $\geqq 1,500$ beds 로 4 구분하였다. 100 499beds 소유병원에서 환자 분포가 $37.4 \%$ 로 가장 많았고 $\geqq 1,500$ beds 병원에서는 $14.8 \%$ 로 가장 적었다.

\section{2. 년령별분포}

년령군별분포를 보면 $30 \sim 34$ 세군에서 $22.6 \%$ 로서 가 장 많았고 70 세이상이 $1.4 \%$ 로 가장 낮았는데 전반적으 로 볼때 중장년층에서 $60 \%$ 이상을 차지하고 있었다. 평 균년령은 38.4 이였다.

\section{3. 환자의 출생지역별 분포}

환자의 출생지역별로 보면 South Atlantic $24.1 \%$ 로 서 가장 논고, 다음이 East South Central 16. $2 \%$, West South Central $14.3 \%$, 가장 낮은 율은 산악지대 출생 자 $1.7 \%$ 였다. 혹인종이나 백인종간의 출생 지역별 통 계학적인 유의한 차이는 없었다.

\section{4. 환자거주지역렬 분포}

환자의 거주지역별로 보아 흑인종이나 백인종간에 통 계학적인 유의한 차이를 보이지 않았다.

5 . 직업분류별 분포

직업분류에 따라 유의한 차이를 보이고 있는데 특히 판매직업 및 전문적인 직업을 가진자가 Sarcoidosis 와 크게 관계되는 것으로 나타났다. $(\mathrm{P}<0.02)$

6. Sarcoidosis 와 Pulmonary Tuberculosis 임싱적으 로 420 Sarcoidosis cases 중에서 $10.2 \%$ 가 폐결헥을 가 지고 있으며, Control 군에서는 $8.1 \%$ 가 폐결핵이였다.

Table 1. Per cent of bronchitis and emphysema, and pulmonary tuberculosis among newly diagnosis sarcoidosis cases and their matched control by race.

\begin{tabular}{|c|c|c|c|c|c|c|}
\hline \multirow[b]{2}{*}{ selected diseases } & \multicolumn{2}{|c|}{ Negro } & \multicolumn{2}{|c|}{ White } & \multicolumn{2}{|c|}{ Total } \\
\hline & $\begin{array}{r}\text { Cases } \\
\mathrm{N}=177\end{array}$ & $\begin{array}{c}\text { Controls } \\
\mathrm{N}=177\end{array}$ & $\begin{array}{c}\text { Cases } \\
\mathrm{N}=138\end{array}$ & $\begin{array}{c}\text { Controls } \\
\mathrm{N}=138\end{array}$ & $\begin{array}{c}\text { Cases } \\
\mathrm{N}=315\end{array}$ & $\begin{array}{c}\text { Controls } \\
N=315\end{array}$ \\
\hline Bronchitis and Emphysema & $6.2 \%$ & $2.3 \%$ & $6.5 \%$ & $2.2 \%$ & $* 6.3 \%$ & $* 2.2 \%$ \\
\hline Pulmonary Tuberculosis & 4.5 & 2.3 & 5.1 & 3.6 & 4.8 & 2.9 \\
\hline None of these & 89.3 & 95.4 & 88.4 & 94.2 & 88.9 & 94.9 \\
\hline
\end{tabular}

$* \mathrm{P}<0.025$ 
결핵 및 호홉기질환 Vol. 19, No. 1, Jan., 1972

그러나 새로이 진단된 315 cases 에 있어서는 $5 \%$ 가 폐 결핵, control 군에서는 $3 \%$ 였다. (표 1 참조)

7. Sarcoidosis 환자의 사방 및 생존율 Sarcoidosis 환 자에서 사망한 자는 모두 56 명이였는데 사망진단서가 확실한 것은 25 명으로 흑인 11 명, 백인 14 명이였다.

사망 진단서를 통해서 볼때 Sarcoidosis가 확실한 사 인으로 될수 있는 것은 혹인사망자 11 명중에서 $36.4 \%$, 백인 14 명중에서는 $28.6 \%$ 이였다.

5년간 생존율을 보면 누적율로 보아서 년령이 높아짐 에 따라서 감소되고 있는데 특히 년령이 25 44세 사이 에 생존자와 일반 인구군이 유의한 차이를 보이고 있다

Table 2. Cumulative 5-year rates of survival for sarcoidosis cases and United States males of the cases' age $\&$ race

\begin{tabular}{r|r|r|r|r|r}
\hline $\begin{array}{c}\text { Age } \\
\text { (years) }\end{array}$ & No. & \multicolumn{2}{|c|}{ cases } & \multicolumn{2}{|c}{\begin{tabular}{c} 
United states males \\
\cline { 3 - 6 } error
\end{tabular}} \\
\hline$<25$ & 12 & 100.00 & 0.00 & 99.28 & 2.49 \\
$25-34$ & 177 & 93.25 & 1.88 & 98.65 & 0.87 \\
$35-44$ & 143 & 90.92 & 2.40 & 97.67 & 1.26 \\
$45-54$ & 54 & 90.75 & 3.95 & 95.27 & 2.88 \\
$55-64$ & 14 & 64.30 & 12.81 & 89.73 & 8.12 \\
$65+$ & 20 & 60.00 & 10.95 & 79.15 & 9.08 \\
\hline Total & 420 & 89.77 & 1.48 & 96.68 & 0.87 \\
\hline
\end{tabular}

흑인이나 백인간에 생존율은 유사하였다.

폐결핵이나, Bronchitis, Emphysema가 있는 cases 는 통계학적으로 유의한 survival rate 를 보이고 있지 않았다. (표 2,3 참조)

Table 3. Cummulative 5-year rates of survival for sarcoidosis cases by race and presence or absence of selected diseases

\begin{tabular}{l|r|r|r}
\hline \multicolumn{1}{c|}{$\begin{array}{c}\text { Cases by race and } \\
\text { selected diseases }\end{array}$} & No. & Rate & $\begin{array}{c}\text { Standard } \\
\text { error }\end{array}$ \\
\hline Total Sarcoidosis & 420 & 89.77 & 1.48 \\
Negroes & 234 & 87.60 & 2.28 \\
Whites & 186 & 92.52 & 1.95 \\
Pulmonary Tuberculosis & & & \\
Present & 43 & 84.38 & 5.76 \\
Absent & 377 & 90.37 & 1.59 \\
Bronchitis and Emphysema & & & \\
Present & 30 & 80.17 & 5.94 \\
Absent & 390 & 90.30 & 1.57 \\
Malignant Neoplasms & & & \\
Present & 10 & $* 82.59$ & 2.59 \\
Absent & 410 & $* 89.90$ & 1.56 \\
\hline P $<0.05$
\end{tabular}

$* \mathrm{P}<0.05$ 